\title{
High density process to cultivate Lactobacillus plantarum biomass using wheat stillage and sugar beet molasses
}

\author{
Małgorzata Krzywonos ${ }^{1} \square \cdot$ Thomas Eberhard $^{2}$ \\ 1 Department of Bioprocess Engineering, Wrocław University of Economics, Poland \\ 2 Department of Microbiology, Uppsala Genetic Centre, Swedish University of Agricultural Sciences, Sweden
}

$\triangle$ Corresponding author: malgorzata.krzywonos@ue.wroc.pl

Received November 26, 2010 / Accepted January 25, 2011

Published online: March 15, 2011

(C) 2011 by Pontificia Universidad Católica de Valparaíso, Chile

\begin{abstract}
Background: Owing to the growing interest in biofuels, the concept of a biorefinery where biomass is converted to a variety of useful products is gaining ground. We here present how distillery waste is combined with a by-product from a sugar production, molasses, to form a medium for the growth of Lactobacillus plantarum with yields and biomass densities comparable with conventional industrial media. Such approach enables a cost-effective utilization of the problematic wastewater from ethanol and a by-product from sugar production. It is the first approach that attempts to find low-cost media for the production of Lactobacillus plantarum biomass.

Results: This study suggests that sieved wheat stillage enriched by adding $1.77 \mathrm{~g} / \mathrm{l}$ yeast extract and $10 \%$ molasses ( $\mathrm{v} / \mathrm{v})$, with $\mathrm{NH}_{4} \mathrm{OH}$ used for $\mathrm{pH}$ adjustment, may be used as a media for large-scale cultivation of $L$. plantarum. Such composition of the medium permits a high density of lactic acid bacteria $\left(1.6 \times 10^{10} \mathrm{cfu} / \mathrm{ml}\right)$ to be achieved.

Conclusions: The use of a fermentation medium consisting of distillery wastewater and molasses to obtain value-added products (such as LAB biomass and lactic acid) is a possible step for classical ethanol production to move towards a biorefinery model production in which all by and waste products are utilized to increase produced values and reduce waste production. This enables a cost-effective utilization of the problematic wastewater from ethanol and sugar production.
\end{abstract}

Keywords: distillery wastewater, high density fermentation, lactic acid bacteria, Lactobacillus plantarum, sugar beet molasses, wheat stillage

\section{INTRODUCTION}

Lactic acid bacteria (LAB) have been used by humans since prehistoric times in the production of various foods as preservatives and to add flavour (Briens et al. 2008). The Nobel laureate Ilya Mechnikov introduced the concept of using bacteria in food to modify the gut microflora to improve human health, calling the concept probiotics. Recently probiotics have also been used in animals. European restrictions on the use of antibiotics in feed for farm animals have enhanced interest in alternative to antibiotics to curb infectious diseases at farms. One such alternative is the large-scale application of probiotic bacteria in animal feed (Gaggia et al. 2010); this is why the potential market for LAB biomass is greatly increasing (Schiraldi et al. 2003; Briens et al. 2008; Wohlgemuth et al. 2010).

$\mathrm{LAB}$ are reported to be extremely fastidious organisms with numerous growth requirements. They need rich media containing compounds such as amino acids, peptides, vitamins and nucleic acids (Narayanan et al. 2004; Dumbrepatil et al. 2008). MRS (De Man, Rogosa, Sharpe broth) is amongst the media most commonly used for Lactobacillus growth; nevertheless, it has some major 
disadvantages, e.g. a complex composition. Another major disadvantage is that the medium includes components too costly for industrial applications.

One of the most widespread Lactobacillus species used in food technology is Lactobacillus plantarum. Pertinent studies reported in the literature have been conducted to find less expensive media supporting Lactobacillus growth. Those found contained carbohydrate and/or nitrogen sources such as wheat flour hydrolysate (Hofvendahl and Hahn-Hägerdal, 1997), wheat bran (Naveena et al. 2005), hydrolysates of wheat bran combined with corn steep liquor (Li et al. 2010), lactose and whey permeate (Fu and Mathews, 1999), whey solely (Mondragón-Parada et al. 2006), hydrolysates of fish viscera (Horn et al. 2005), corn steep liquor, cane molasses with animal and marine by-products (Demirci et al. 1998), and molasses solely (Tondee and Sirianuntapiboon, 2008). It is essential to note that all of those studies were aimed at optimizing the medium for lactic acid production. Only a few reports can be found in the literature on a high density processes to culture lactic acid biomass e.g. Lactobacillus casei (Aguirre-Ezkauriatza et al. 2010) and Lactobacillus delbrueckii ssp. bulgaricus (Schiraldi et al. 2003). The work reported on in this paper is the first one that attempts to find low-cost media for the production of Lactobacillus plantarum biomass.

LAB are typically used as starter cultures in the dairy industry. They may also be used as preservatives in fodder (Briens et al. 2008; Ye et al. 2008). In such applications, they are known to inhibit the growth of microbial pathogens and spoilage organisms, or increase digestibility; but they may also display probiotic effects. Another use for LAB is as an animal probiotic in its own right (Gaggia et al. 2010). However, the use of LAB are not restricted to food and feed, they have recently been used in weed control on golf courses (Omer et al. 2010).

The aim of this study was to obtain a low-cost medium for an industrial scale production of Lactobacillus plantarum biomass. For this purpose, a preliminary experimental study was conducted, where we used wheat stillage and sugar beet molasses as carbohydrate and/or nitrogen sources.

Table 1. Characterization of wheat stillage.

\begin{tabular}{|c|c|}
\hline Parameter & Content \\
\hline $\mathrm{pH}$ & $4.0-4.1$ \\
\hline Water content [\%] & $95-97.1$ \\
\hline $\mathrm{N}-\mathrm{NH}_{4}[\mathrm{~g} / \mathrm{kg}]$ & $0.5-0.8$ \\
\hline Protein nitrogen x 6.25 (Kjeldahl) [\%] & $1.2-2.3$ \\
\hline Phosphorus, $\mathrm{P}$ [mg/l] & $54-60$ \\
\hline Glucose $[\mathrm{g} / 100 \mathrm{~g}]$ & $<0.04$ \\
\hline Lactic acid $[\mathrm{g} / \mathrm{l}]$ & 3.26 \\
\hline Acetic acid $[\mathrm{g} / \mathrm{l}]$ & 5.52 \\
\hline Propionic acid [g/l] & 7.28 \\
\hline Butyric acid $[\mathrm{g} / \mathrm{l}]$ & 0.65 \\
\hline
\end{tabular}

\section{METHODS}

\section{Microorganism}

Lactobacillus plantarum MiLAB 393 was kept frozen in a 20\% (w/v) glycerol solution until use.

\section{Inoculum preparation}

The preparation of inoculum commenced with the transfer of the frozen microorganism to a $100 \mathrm{ml}$ flask containing $50 \mathrm{ml}$ of MRS medium (Oxoid CM0359B, Basingstoke, England) under aseptic conditions. The flask was incubated at $37^{\circ} \mathrm{C}$ for $24 \mathrm{hrs}$ before use in the experiments. Inoculum volume for biomass production comprised $7.5 \mathrm{ml}$ of bacteria grown on MRS medium. 
Media

Distillery wastewater (wheat stillage, by-product of ethanol distillation, with parameters itemized in Table 1) was used as a medium for bacteria cultivation. Before use, solid particles were removed from the stillage in two ways: (1) filtration through filter paper, or (2) sieving $(0.45 \mathrm{~mm} \mathrm{mesh})$. The liquid phases obtained after separation were stored at $4^{\circ} \mathrm{C}$ before incorporation into growth media.

Wheat stillage was enriched with the following ingredients: glucose (G; BHD, WWR International, Leuven, Belgium; 20 g/l), molasses (M; Danisco, Malmö, Sweden; 5, 10\% v/v), salts (S; 5 g/l K $\mathrm{HPO}_{4}$, Scharlau PO 0258, Barcelona, Spain; and $0.75 \mathrm{~g} / \mathrm{MgSO}_{4}$, Scharlau MA 0085, Barcelona, Spain), peptone (P; Oxoid LP LP0037B, Basingstoke, England; $5.08 \mathrm{~g} / \mathrm{l}$ ), and yeast extract (YE; Oxoid LP 0021, Basingstoke, England; 1.77, 2.65, 3.54, 5.31, 7.08 and $10.62 \mathrm{~g} / \mathrm{l})$. Glucose and molasses were added separately after sterilization of the stillage and additives at $121^{\circ} \mathrm{C}$ for $15 \mathrm{~min}$.

\section{Process conditions}

All fermentations were conducted at $37^{\circ} \mathrm{C}$ in $250 \mathrm{ml}$ shake flasks (containing $150 \mathrm{ml}$ of the medium) at $120 \mathrm{rev} / \mathrm{min}$ (Lab-Term incubator, Adolp Kühnes AG, Schweiz). The pH was held at 6.0 by the automated addition of $25 \%$ (w/v) $\mathrm{NaOH}$ or $25 \% \mathrm{NH}_{4} \mathrm{OH}$ (Scharlau, Sentemenat, Spain). The $\mathrm{pH}$ was controlled by a pH control unit (Inventron, Kungsbacka Sweden) using P2 peristaltic pumps (Belach, Solna, Sweden). The autoclavable electrodes (Bradly James, Irvine California, USA) were used to measure $\mathrm{pH}$ value. The analogue output from the $\mathrm{pH}$ control unit was sent to an NI-USB-6218 AD converter, which is connected to a computer. National Instruments VI logger software has been used to collect the data.

All experiments were conducted aseptically in duplicate and average values are reported.

Table 2. Supplementation of filtered stillage.

\begin{tabular}{|c|c|c|c|c|c|}
\hline Composition of the medium* & $\begin{array}{c}\text { Glucose } \\
\text { conversion } \\
{[\%]}\end{array}$ & $\begin{array}{l}\operatorname{Max} L A \\
{[g / l]}\end{array}$ & $\begin{array}{c}\text { Maximal } \\
\text { number of LAB } \\
{[\mathrm{cfu} / \mathrm{ml}]}\end{array}$ & $\begin{array}{c}Y_{\mathrm{P} / \mathrm{S}} \\
{[\mathrm{g} / \mathrm{g}]^{\star *}}\end{array}$ & $\begin{array}{c}Q_{p} \\
{[g /(l \cdot h)]^{\star \star}}\end{array}$ \\
\hline Stillage & - & 0.98 & $4.8 \times 10^{5}$ & - & - \\
\hline Stillage + Glu & $\begin{array}{c}12.7 \\
{[48 \mathrm{~h}]}\end{array}$ & $\begin{array}{c}2.9 \\
{[24 \mathrm{~h}]}\end{array}$ & $4.4 \times 10^{7}$ & 0.89 & 0.08 \\
\hline Stillage + Glu + Salts & $\begin{array}{c}78.9 \\
{[36 \mathrm{~h}]}\end{array}$ & $\begin{array}{l}14.8 \\
{[36 \mathrm{~h}]}\end{array}$ & $9 \times 10^{7}$ & 0.99 & 0.62 \\
\hline Stillage + Glu + Salts + P & $\begin{array}{c}100 \\
{[24 \mathrm{~h}]}\end{array}$ & $\begin{array}{l}19.5 \\
{[24 \mathrm{~h}]}\end{array}$ & $4 \times 10^{9}$ & 1.11 & 0.81 \\
\hline Stillage + Glu + Salts + YE & $\begin{array}{c}100 \\
{[12 \mathrm{~h}]}\end{array}$ & $\begin{array}{l}19.6 \\
{[24 \mathrm{~h}]}\end{array}$ & $4.4 \times 10^{9}$ & 1.04 & 0.82 \\
\hline Stillage + Glu + Salts + YE $+P$ & $\begin{array}{c}100 \\
{[12 \mathrm{~h}]}\end{array}$ & $\begin{array}{l}20.5 \\
{[12 \mathrm{~h}]}\end{array}$ & $31.8 \times 10^{9}$ & 1.06 & 0.85 \\
\hline Stillage $+M$ & $\begin{array}{l}63.6 \\
{[48 \mathrm{~h}]}\end{array}$ & $\begin{array}{l}15.5 \\
{[48 \mathrm{~h}]}\end{array}$ & $8.9 \times 10^{8}$ & 0.84 & 0.64 \\
\hline
\end{tabular}

${ }^{*} \mathrm{YE}=$ Yeast Extract $(5.31 \mathrm{~g} / \mathrm{l}), \mathrm{Glu}=$ Glucose $(2 \%), \mathrm{M}=$ Molasses (5\%), Salts $\left(5 \mathrm{~g} / \mathrm{K} \mathrm{K}_{2} \mathrm{HPO}_{4} ; 0.75 \mathrm{~g} / \mathrm{l} \mathrm{MgSO}_{4}\right), \mathrm{P}=$ Peptone (5.08 $\mathrm{g} / \mathrm{l}) .{ }^{*} \mathrm{G}$ lucose conversion, $\mathrm{Y}_{\mathrm{P} / \mathrm{S}}$ and $\mathrm{Q}_{\mathrm{P}}$ were calculated for values obtained in the $24 \mathrm{hrs}$ of the process.

\section{Analytical methods}

Increases in biomass (cfu/ml) were determined by plating serial dilutions on MRS agar. The plates were assessed after $48 \mathrm{hrs}$ of incubation at $37^{\circ} \mathrm{C}$. The concentrations of organic acids (lactic, propionic, acetic, isobutyric and butyric) and sugars (glucose, fructose and sucrose) were analyzed by HPLC (column, Rezex ROA Organic Acid $\mathrm{H}^{+}(8 \%), 300 \times 7.8 \mathrm{~mm}$, Phenomenex, at ambient temperature; eluent: $5 \mathrm{mM} \mathrm{H}_{2} \mathrm{SO}_{4}$ at $0.6 \mathrm{ml} / \mathrm{min}$; injection, $5 \mu \mathrm{l}$; detector, RID).

Sugars content was expressed as glucose concentration to obtain comparable results. Glucose conversion was calculated as the difference between the initial and final concentration in the medium in proportion to the initial concentration value. The maximum concentration of lactic acid produced (max $\mathrm{LA}, \mathrm{g} / \mathrm{l}$ ) was calculated as the maximal detected value minus the initial lactic acid content. Lactic acid 


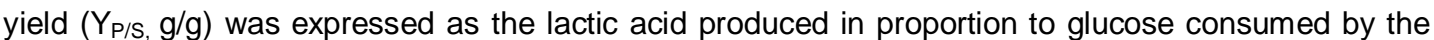
bacteria on a weight basis $(\mathrm{g} / \mathrm{g})$. Calculations were performed for glucose equivalent in order to obtain comparable results. Volumetric productivity of lactic acid $\left(Q_{p},(g /(l \cdot h))\right)$ was defined as the maximum quantity of lactic acid formed per litre of fermentate per hr.

\section{RESULTS}

\section{Supplementation of filtered stillage}

Table 2 summarizes the results obtained when wheat stillage filtrate (filter paper) was used as the fermentation medium for LAB growth, with and without combinations of supplements. With nonsupplemented stillage, the maximal quantity of lactic acid produced (max LA) and the maximal number of LAB were only $0.98 \mathrm{~g} / \mathrm{l}$ and $4.8 \times 10^{5} \mathrm{cfu} / \mathrm{ml}$, respectively. The composition of the wheat stillage (Table 1) suggests that the low level of sugars may have been a limiting factor in the process. The addition of glucose (2\%) had a beneficial effect on both maximal number of LAB and max LA, which totaled $4.4 \times 10^{7} \mathrm{cfu} / \mathrm{ml}$ and $2.9 \mathrm{~g} / \mathrm{l}$, respectively. Addition of glucose solely increased the max LA value approx. threefold (Table 2). However, only $12.7 \%$ of the glucose added was converted during fermentation (48 hrs). This might be the reason why the theoretical yield of LA content was as low as $16 \%$. The addition of salts $\left(\mathrm{K}_{2} \mathrm{HPO}_{4}, \mathrm{MgSO}_{4}\right)$ enhanced glucose conversion 6.2 -fold (to $78.9 \%$ ) and max LA concentration 5.2-fold (to $14.8 \mathrm{~g} / \mathrm{l}$ ). There was also a 7.4-fold increase in productivity and a $9.8 \%$ increase in lactic acid yield. Substantially higher values were obtained using a medium enriched with glucose, salts and peptone. In that medium, the maximal number of LAB increased to $4 \times 10^{9}$ $\mathrm{cfu} / \mathrm{ml}$, and the max LA produced was by $24 \%$ higher than in the similar medium with no peptone enrichment. All the glucose present in the medium was utilized during the first $24 \mathrm{hrs}$ of the process.

Replacement of peptone with yeast extract (YE) produced similar results. The maximal LAB grown and LA produced were $4.4 \times 10^{9} \mathrm{cfu} / \mathrm{ml}$ and $19.6 \mathrm{~g} / \mathrm{l}$, respectively. Supplementation of the stillage with glucose, salts, and both peptone and YE raised the maximal number of LAB and LA concentration to $31.8 \times 10^{9} \mathrm{cfu} / \mathrm{ml}$ and $20.5 \mathrm{~g} / \mathrm{l}$, respectively (Table 2). In order to improve the cost-effectiveness of the process, glucose was replaced with sugar beet molasses (5\%). In the molasses-enriched medium the assimilation of carbohydrates (expressed as glucose equivalent), the maximal number of $L A B$, and the max LA synthesized were higher $\left(63.6 \%, 8.9 \times 10^{8} \mathrm{cfu} / \mathrm{ml}, 15.5 \mathrm{~g} / \mathrm{l}\right)$ whereas lactic acid yield remained at approximately the same level $(0.84 \mathrm{~g} / \mathrm{g})$. The value of the theoretical lactic acid yield for the molasses-enriched medium was 3-fold higher than the value obtained for the pure-glucose supplemented medium. The highest LA productivity $\left(Q_{P}\right)(0.85 \mathrm{~g} /(\mathrm{l} \cdot \mathrm{h}))$ was observed when the medium was enriched with glucose, salts, $Y E$ and peptone. The lowest $Q_{p}$ value was obtained in the experiment where glucose was the sole supplement $(0.08 \mathrm{~g} /(\mathrm{l} \cdot \mathrm{h}))($ Table 2$)$.

Table 3. Supplementation of filtered stillage with yeast extract (YE) and molasses (5\% and 10\%); $\mathrm{pH}$ controlled with $\mathrm{NH}_{4} \mathrm{OH}$.

\begin{tabular}{|c|c|c|c|c|c|c|}
\hline \multirow{2}{*}{ Parameter } & \multicolumn{3}{|c|}{$5 \% M$} & \multicolumn{3}{|c|}{$10 \% \mathrm{M}$} \\
\hline & 2.65g/l YE & 5.31g/l YE & $10.62 \mathrm{~g} / \mathrm{YE}$ & $2.65 \mathrm{~g} / \mathrm{YE}$ & $5.31 \mathrm{~g} / \mathrm{YE}$ & $10.62 \mathrm{~g} / \mathrm{YE}$ \\
\hline Glucose conversion [\%] ${ }^{*}$ & 100 & 100 & 100 & 67.2 & 99.9 & 99.8 \\
\hline $\operatorname{Max}$ LA [g/l] & $\begin{array}{c}21.6 \\
{[32 \mathrm{~h}]}\end{array}$ & $\begin{array}{c}25.0 \\
{[32 \mathrm{~h}]}\end{array}$ & $\begin{array}{c}27.6 \\
{[24 \mathrm{~h}]}\end{array}$ & $\begin{array}{c}38.6 \\
{[48 \mathrm{~h}]}\end{array}$ & $\begin{array}{c}41.2 \\
{[24 \mathrm{~h}]}\end{array}$ & $\begin{array}{c}40.9 \\
{[24 \mathrm{~h}]}\end{array}$ \\
\hline $\begin{array}{l}\text { Maximal number of LAB } \\
\text { [cfu/ml] }\end{array}$ & $\begin{array}{c}2.4 \times 10^{9} \\
{[12 \mathrm{~h}]}\end{array}$ & $\begin{array}{c}2.8 \times 10^{9} \\
{[12 \mathrm{~h}]}\end{array}$ & $\begin{array}{c}3.4 \times 10^{9} \\
{[12 \mathrm{~h}]}\end{array}$ & $\begin{array}{c}3.1 \times 10^{9} \\
{[12 \mathrm{~h}]}\end{array}$ & $\begin{array}{c}3.0 \mathrm{x} \\
10^{9} \\
{[12 \mathrm{~h}]}\end{array}$ & $\begin{array}{c}3.6 \times 10^{9} \\
{[12 \mathrm{~h}]}\end{array}$ \\
\hline$Y_{P / S}[g / g]^{*}$ & $\begin{array}{c}0.74 \\
(74 \%)^{a}\end{array}$ & $\begin{array}{c}0.84 \\
(84 \%)^{a}\end{array}$ & $\begin{array}{c}0.945 \\
(94.4 \%)^{\mathrm{a}}\end{array}$ & $\begin{array}{c}0.665 \\
(44.7 \%)^{\mathrm{a}}\end{array}$ & $\begin{array}{c}0.895 \\
(89 \%)^{\mathrm{a}}\end{array}$ & $\begin{array}{c}0.86 \\
(86 \%)^{a}\end{array}$ \\
\hline$Q_{P}[g /(l \cdot h)]^{*}$ & 0.89 & 1.04 & 1.15 & 0.94 & 1.72 & 1.70 \\
\hline
\end{tabular}

${ }^{*}$ Glucose conversion, $\mathrm{Y}_{\mathrm{P} / \mathrm{S}}$ and $\mathrm{Q}_{\mathrm{P}}$ were calculated for values obtained in the $24 \mathrm{hrs}$ of the process. ${ }^{\mathrm{a}} \%$ of the theoretical yield. 


\section{Filtered stillage supplemented with yeast extract and molasses}

In this experimental series (Table 3), a medium enriched with molasses (5\% and 10\%) was supplemented with various amounts of $\mathrm{YE}$; the neutralizing agent being $\mathrm{NH}_{4} \mathrm{OH}$. The maximal number of $L A B$ produced ranged from 2.4 to $3.62 \times 10^{9} \mathrm{cfu} / \mathrm{ml}$ in all formulations. Doubling the quantity of molasses and increasing the quantity of YE 4-fold caused the LAB biomass and LA production to rise (Table 2 and Table 3).

In the processes using molasses-enriched media (5\% addition), the yield of lactic acid production ( $\mathrm{Y} P / \mathrm{S})$ increased with the amount of YE added, the highest value being measured at the highest YE concentration (10.62 g/l) (Table 3). With $10 \%$ molasses, the highest values of $\mathrm{Y}_{\mathrm{P} / \mathrm{S}}$ and $\mathrm{Q}_{\mathrm{p}}$ were observed at a considerably lower YE concentration (5.31 g/l) (Table 3).

\section{Supplementation of sieved stillage}

These experiments were conducted in the liquid phase of the stillage after removal of solids by sieving $(0.45 \mathrm{~mm})$. The aim was to examine how the method of solids separation affects LA synthesis and LAB growth. The results are summarized in Table 4 . When the sieved stillage was not enriched, the max LA value $(1.08 \mathrm{~g} / \mathrm{l})$ and the maximal number of LAB $\left(5.7 \times 10^{5} \mathrm{cfu} / \mathrm{ml}\right)$ were similar to those achieved with the non-enriched filtered stillage (Table 2). When sieved stillage was supplemented with glucose, the maximal number of $\operatorname{LAB}\left(4.6 \times 10^{8} \mathrm{cfu} / \mathrm{ml}\right)$ was higher than that supported by either the nonsupplemented sieved stillage (Table 4) or the filtered glucose stillage (Table 2). The replacement of glucose with molasses increased the max LA value and the maximal number of LAB (17.11 $\mathrm{g} / \mathrm{l}$ and 9.5 $\times 10^{8} \mathrm{cfu} / \mathrm{ml}$, respectively). The values of these parameters, as well as those of $\mathrm{Y}_{\mathrm{P} / \mathrm{S}}$ and $\mathrm{Q}_{\mathrm{P}}$, were higher than the values attained using filtered stillage with either glucose or molasses enrichment (Table 2 and Table 4).

Table 4. Supplementation of sieved stillage.

\begin{tabular}{|c|c|c|c|c|c|}
\hline $\begin{array}{l}\text { Composition of } \\
\text { the medium }\end{array}$ & $\begin{array}{c}\text { Glucose } \\
\text { conversion } \\
{[\%]}\end{array}$ & $\operatorname{Max}$ LA [g/l] & $\begin{array}{l}\text { Maximal number } \\
\text { of LAB [cfu/ml] }\end{array}$ & $\begin{array}{c}Y_{P / S} \\
{[g / g]^{*}}\end{array}$ & $\begin{array}{c}Q_{p} \\
{[g /(l \cdot h)]^{*}}\end{array}$ \\
\hline Stillage & - & 1.08 & $\begin{array}{c}5.7 \times 10^{5} \\
{[24 \mathrm{~h}]}\end{array}$ & - & - \\
\hline Stillage $+2 \%$ Glu & $\begin{array}{c}14.4 \\
{[48 \mathrm{~h}]}\end{array}$ & $\begin{array}{c}3.64 \\
{[48 \mathrm{~h}]}\end{array}$ & $\begin{array}{c}4.6 \times 10^{8} \\
{[48 \mathrm{~h}]}\end{array}$ & $\begin{array}{c}1.34 \\
(19 \%)^{\mathrm{a}}\end{array}$ & 0.15 \\
\hline Stillage $+5 \% \mathrm{M}$ & $\begin{array}{c}70.7 \\
{[48 \mathrm{~h}]}\end{array}$ & $\begin{array}{l}17.11 \\
{[48 \mathrm{~h}]}\end{array}$ & $\begin{array}{c}9.5 \times 10^{8} \\
{[48 \mathrm{~h}]}\end{array}$ & $\begin{array}{c}0.87 \\
(62 \%)^{\mathrm{a}}\end{array}$ & 0.71 \\
\hline
\end{tabular}

*Glucose conversion, YP/S and QP were calculated for values obtained in the $24 \mathrm{hrs}$ of the process. ${ }^{\mathrm{a}} \%$ of the theoretical yield.

\section{Sieved stillage with molasses and yeast extract supplementation}

Control of $\mathrm{pH}$ with $\mathrm{NaOH}$. The aim of the experiments was to study how the addition of YE $(2.65,5.31$ or $10.62 \mathrm{~g} / \mathrm{l}$ ) and molasses (5\% or $10 \%)$ influences the values of LAB growth, LA production, $Y_{P / S}$ and $\mathrm{Q}_{\mathrm{P}}$, when sieved stillage was used as a medium, and the $\mathrm{pH}$ was controlled using $\mathrm{NaOH}$. Relevant data are compiled in Table 5. The maximal number of LAB ranged between $1.2 \times 10^{9}$ and $4.8 \times 10^{9}$ $\mathrm{cfu} / \mathrm{ml}$. Addition of $5 \%$ molasses and $2.65 \mathrm{~g} / \mathrm{l}$ YE produced the lowest number of $L A B$, whereas that of $10 \%$ molasses and $10.62 \mathrm{~g} / \mathrm{l}$ YE accounted for the highest growth of LAB. LAB numbers peaked at 12 and $24 \mathrm{hrs}$ of the process. The data in Table 5 demonstrate that varying YE concentrations in the medium failed to influence the amount of LA produced, and that the addition of molasses enhanced LA synthesis. With the addition of 5\% molasses, the max LA (26.5-28.9 g/l) was achieved within $24 \mathrm{hrs}$ and $48 \mathrm{hrs}$, respectively. In contrast, the addition of 10\% molasses yielded more LA (48.7-50.2 g/l), but required a longer time (60 hrs) to reach this level. YE addition did not influence the $Q_{P}$ value for formulations with 5\% molasses. However, with 10\% molasses, the $Q_{p}$ value rose from 0.61 to 1.19 $\mathrm{g} /(\mathrm{l} \cdot \mathrm{h})$ with the quantity of $\mathrm{YE}$ added. The $\mathrm{Y}_{\mathrm{P} / \mathrm{s}}$ ratio obtained in $5 \%$ molasses-enriched wheat stillage varied from 0.94 to $1.10 \mathrm{~g} / \mathrm{g}$, whereas that attained with $10 \%$ molasses enrichment was 0.67 to 1.43 g/g. 
Control of $\mathrm{pH}$ with $\mathrm{NH}_{4} \mathrm{OH}$. In this experimental series (Table 6), the quantities of YE added were decreased $(1.77,3.54$ and $7.08 \mathrm{~g} / \mathrm{l})$ but the enrichment of the medium with the carbon source (molasses, $5 \%$ and 10\%) remained the same. The neutralizing agent for $\mathrm{pH}$ control was $\mathrm{NH}_{4} \mathrm{OH}$. It is interesting to note that in all of the experiments, the maximal number of the LAB supported by such media $\left(0.9 \times 10^{10}-1.6 \times 10^{10} \mathrm{cfu} / \mathrm{ml}\right)$ was higher than in the experiment with $\mathrm{pH}$ control using $\mathrm{NaOH}$ $\left(1.2 \times 10^{9}-4.8 \times 10^{9} \mathrm{cfu} / \mathrm{ml}\right)$ (Table 5). The max LA produced varied from 28.2 to $33.1 \mathrm{~g} / \mathrm{l}$ (at $5 \%$ molasses enrichment), and from 39.9 to $49.8 \mathrm{~g} / \mathrm{l}$ (at $10 \%$ molasses supplementation). At $5 \%$ enrichment, the quantity of $\mathrm{YE}$ added had no effect on the value of either $\mathrm{Y}_{\mathrm{P} / \mathrm{S}}$ or $\mathrm{Q}_{\mathrm{P}}$. At $10 \%$ supplementation, the quantity of $\mathrm{YE}$ had some effect on $\mathrm{Q}_{\mathrm{P}}$ and $\mathrm{Y}_{\mathrm{P} / \mathrm{S}}$ (Table 6). The effect of $\mathrm{YE}$ addition on the theoretical yield was observed at $10 \%$ molasses supplementation. As the quantity of the YE added increased, so did the value of the theoretical yield. Regardless of the percentage of enrichment, molasses exerted an influence on both $Q_{P}$ and $Y_{P / S}$. At $5 \%$ enrichment, $Q_{P}$ values were

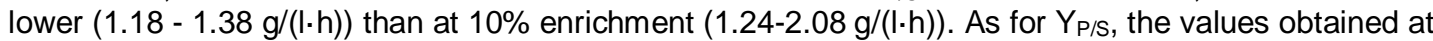
$5 \%$ enrichment were higher $(0.96-1.06 \mathrm{~g} / \mathrm{g})$ than those achieved at $10 \%$ supplementation $(0.84-1.05$ $g / g)$.

\section{DISCUSSION}

These results demonstrate that the combination of wheat stillage medium, sugar beet molasses and YE may give good yields for cultivating lactic acid bacteria. The highest number of the LAB $\left(1.6 \times 10^{10}\right.$ $\mathrm{cfu} / \mathrm{ml}$ ) was achieved by addition of $1.77 \mathrm{~g} / \mathrm{l} \mathrm{YE}$ to the sieved stillage medium containing $10 \%$ of molasses, when $\mathrm{NH}_{4} \mathrm{OH}$ was used for $\mathrm{pH}$ adjustment (Table 6). The results also show that the proportion of molasses influenced the length of time over which the maximal number of LAB was achieved. At $5 \%$ enrichment, the LAB biomass took only $24 \mathrm{hrs}$ to reach the maximal concentration. With twice the amount of molasses, the time to attain maximum LAB biomass also doubled. In molasses-enriched sieved stillage, media the maximal LAB concentrations were higher than in filtered stillage media (Table 3 and Table 5). This may be attributed to some key substances in the solids persisting in the sieved wheat stillage, which had the capacity to support bacterial growth. During our experiments, we achieved a higher amount of LAB $\left(1.6 \times 10^{10} \mathrm{cfu} / \mathrm{ml}\right)$ than did Chauhan et al. $(2.34 \times$ $10^{9} \mathrm{cfu} / \mathrm{ml}$ ) after $48 \mathrm{hrs}$ of Lactobacillus sp. KCP01 production in date juice supplemented with different components (Chauhan et al. 2007). The results of our present study show that wheat stillage supplemented with YE and molasses can be used as a medium for industrial scale production of lactic acid bacteria.

As for the growth of $L$. plantarum NC8 in hydrolysates of fish viscera, Horn et al. (2005) observed that media containing low amounts of YE or fish peptones produced biomass yields only slightly lower (by 10\%) than the yield obtained with MRS medium. Horn et al. (2005) also suggest that the nitrogen sources in the MRS are present in excess, and that they are not assimilated by the biomass. Dumbrepatil et al. (2008) reported in their paper on LAB growth and LA production in YE-enriched cane

Table 5. Supplementation of sieved stillage with yeast extract (YE) and molasses (5\% and 10\%); $\mathrm{pH}$ controlled with $\mathrm{NaOH}$.

\begin{tabular}{|c|c|c|c|c|c|c|}
\hline \multirow[b]{2}{*}{ Parameter } & \multicolumn{3}{|c|}{$5 \% M$} & \multicolumn{3}{|c|}{$10 \% \mathrm{M}$} \\
\hline & 2.65g/l YE & $5.31 \mathrm{~g} / \mathrm{I} \mathrm{YE}$ & 10.62g/l YE & 2.65g/l YE & 5.31g/I YE & $10.62 \mathrm{~g} / \mathrm{YE}$ \\
\hline$\underset{*}{\operatorname{Glucose}} \underset{*}{\mathrm{~s}}$ conversion $[\%]$ & 98.8 & 98.8 & 100 & 39.7 & 35.3 & 67.7 \\
\hline Max LA [g/l] & $\begin{array}{c}28.5 \\
{[36 \mathrm{~h}]}\end{array}$ & $\begin{array}{c}28.9 \\
{[48 \mathrm{~h}]}\end{array}$ & $\begin{array}{c}26.5 \\
{[24 \mathrm{~h}]}\end{array}$ & $\begin{array}{c}49.2 \\
{[60 \mathrm{~h}]}\end{array}$ & $\begin{array}{l}48.7 \\
{[60 \mathrm{~h}]}\end{array}$ & $\begin{array}{c}50.2 \\
{[60 \mathrm{~h}]}\end{array}$ \\
\hline $\begin{array}{c}\text { Maximal number of } \\
\text { LAB } \\
{[\mathrm{cfu} / \mathrm{ml}]}\end{array}$ & $\begin{array}{c}1.2 \times 10^{9} \\
{[24 \mathrm{~h}]}\end{array}$ & $\begin{array}{c}2.7 \times 10^{9} \\
{[24 \mathrm{~h}]}\end{array}$ & $\begin{array}{l}2.3 \times 10^{9} \\
{[24 \mathrm{~h}]}\end{array}$ & $\begin{array}{c}2.2 \times 10^{9} \\
{[24 \mathrm{~h}]}\end{array}$ & $\begin{array}{c}3.4 \times 10^{9} \\
{[12 \mathrm{~h}]}\end{array}$ & $\begin{array}{c}4.8 \times 10^{9} \\
{[12 \mathrm{~h}]}\end{array}$ \\
\hline$Y_{P / S}[g / g] *$ & $\begin{array}{c}1.08 \\
(108 \%)^{a}\end{array}$ & $\begin{array}{c}1.09 \\
(109 \%)^{\mathrm{a}}\end{array}$ & $\begin{array}{c}0.94 \\
(94 \%)^{\mathrm{a}}\end{array}$ & $\begin{array}{l}0.675 \\
(27 \%)^{a}\end{array}$ & $\begin{array}{c}1.43 \\
(50 \%)^{\mathrm{a}}\end{array}$ & $\begin{array}{c}0.81 \\
(54 \%)^{\mathrm{a}}\end{array}$ \\
\hline$Q_{p}[g /(I \cdot h)]^{*}$ & 1.11 & 1.04 & 1.10 & 0.61 & 1.14 & 1.19 \\
\hline
\end{tabular}

${ }^{*}$ Glucose conversion, $Y_{P / S}$ and $Q_{P}$ were calculated for values obtained in the $24 \mathrm{hrs}$ of the process. ${ }^{{ }^{a}} \%$ of the theoretical yield. 
molasses that the requirement of a low amount of YE as nitrogen source could be attributed to the fact that the quantity of nitrogen in the molasses was sufficient to support LAB growth. In our present study, YE addition to the molasses-enriched medium (5\%) provided an almost complete assimilation of carbohydrates (expressed as glucose) after 24 hrs (Table 3, Table 5 and Table 6). Upon 10\% enrichment with molasses, YE addition also produced a high extent of carbohydrates assimilation. However, for sieved stillage with $\mathrm{pH}$ controlled by $\mathrm{NaOH}$, the proportion of carbohydrates assimilated over the same period was substantially lower (Table 5).

The neutralizer used for $\mathrm{pH}$ control also influences the maximum obtainable biomass of LAB. Results from our studies revealed that the amount of growth obtained for each culture neutralized with ammonium hydroxide was greater than that when sodium hydroxide was the neutralizer (Table 5 and Table 6). The same observation has been done by Gilliland who studied the effect of neutralizing agent on preparation of starter cultures of lactic streptococci (Gilliland, 1976). The higher amount of LAB obtained with $\mathrm{NH}_{4} \mathrm{OH}$ as the neutralizer may have been due to the $\mathrm{NH}_{4}^{+}$being stimulatory to the cultures. Peebles et al. (1969) suggested that the $\mathrm{NH}_{3}$ may have raised the intracellular $\mathrm{pH}$ more rapidly than $\mathrm{NaOH}$, thus allowing a more optimum $\mathrm{pH}$ for cell growth, resulting in a higher growth which was achieved in a shorter period. The ammonia could also serve as a nitrogen source for bacteria. It is possible that lower biomass amount observed when $\mathrm{NaOH}$ was used as neutralizer was due to the $\mathrm{Na}^{+}$ being inhibitory (Peebles et al. 1969).

According to literature, sugar beet molasses typically consists of approximately $50 \%$ carbohydrates, where sucrose, glucose and other sugars account for $96 \%, 3 \%$ and $1.4 \%$, respectively (Ghazi et al. 2006). The total sugar content of molasses used in our study was $53 \% \mathrm{w} / \mathrm{v}$. In the medium with $5 \%$ molasses, total sugar concentration expressed as glucose equivalent was slightly higher than in $2 \%$ glucose medium, and approximately twice as high as in the $10 \%$ molasses medium $(25.8 \pm 0.8 \mathrm{~g} / \mathrm{l}, 20 \pm$ $0.2 \mathrm{~g} / \mathrm{l}$, and $53.4 \pm 0.6 \mathrm{~g} / \mathrm{l}$, respectively). The optimum concentration of molasses in the medium could be somewhere between $5 \%$ and $10 \%$. In our study the amount of molasses added was not optimized; it was adopted on the basis of relevant literature (Göksungur and Güvenç, 1999).

L. plantarum is known to be homofermentative for hexoses, producing 2 mol lactic acid per mol of hexoses (Passos et al. 1994). In our experiments using molasses-enriched media, we converted the yield of lactic acid into the glucose equivalent, to enable comparisons. The reason why the product obtained from the $2 \%$ glucose medium was lower compared with the one obtained from the $5 \%$ molasses medium (Table 2 and Table 4) could be that molasses contains also other components (e.g. other sugars, vitamins, amino acids, trace elements), which might enhance the yield of the product. In some of the processes, the actual yield of lactic acid was higher than the theoretical yield (Table 2 to Table 6). The explanation as to why the values of lactic acid yield were higher than those of the theoretical yield can be found in the utilization of other sugars (e.g. rafinose) that were present in the molasses. Another explanation was proposed by Ohmomo et al. (1988) who suggested that the LAB converted the melanoidins that were present in the molasses into lactic acid. Mussatto et al. (2008) report $Y_{P / S}$ ratios higher than $0.81 \mathrm{~g} / \mathrm{g}$, obtained with brewer's spent grain hydrolysate.

Table 6. Supplementation of sieved stillage with yeast extract (YE) and molasses (5\% and 10\%); $\mathrm{pH}$ controlled with $\mathrm{NH}_{4} \mathrm{OH}$.

\begin{tabular}{|c|c|c|c|c|c|c|}
\hline \multirow[b]{2}{*}{ Parameter } & \multicolumn{3}{|c|}{$5 \% \mathrm{M}$} & \multicolumn{3}{|c|}{$10 \% \mathrm{M}$} \\
\hline & $1.77 \mathrm{~g} / \mathrm{YE}$ & $3.54 \mathrm{~g} / \mathrm{l} \mathrm{YE}$ & $7.08 \mathrm{~g} / \mathrm{l} \mathrm{YE}$ & $1.77 \mathrm{~g} / \mathrm{YE}$ & $3.54 \mathrm{~g} / \mathrm{YE}$ & $7.08 \mathrm{~g} / \mathrm{l} \mathrm{YE}$ \\
\hline Glucose conversion [\%] ${ }^{*}$ & 100 & 100 & 100 & 51.1 & 82.7 & 99.8 \\
\hline $\operatorname{Max} L A[g / l]$ & $\begin{array}{l}33.1 \\
{[24]}\end{array}$ & $\begin{array}{c}28.4 \\
{[36 \mathrm{~h}]}\end{array}$ & $\begin{array}{c}28.2 \\
{[24 \mathrm{~h}]}\end{array}$ & $\begin{array}{c}39.9 \\
{[48 \mathrm{~h}]}\end{array}$ & $\begin{array}{c}47.6 \\
{[36 \mathrm{~h}]}\end{array}$ & $\begin{array}{c}49.8 \\
{[24 \mathrm{~h}]}\end{array}$ \\
\hline $\begin{array}{l}\text { Maximal number of LAB } \\
\text { [cfu/ml] }\end{array}$ & $\begin{array}{c}1.3 \times 10^{10} \\
{[24 \mathrm{~h}]}\end{array}$ & $\begin{array}{c}0.9 \times 10^{10} \\
{[24 \mathrm{~h}]}\end{array}$ & $\begin{array}{c}1.3 \times 10^{10} \\
{[24 \mathrm{~h}]}\end{array}$ & $\begin{array}{c}1.6 \times 10^{10} \\
{[48 \mathrm{~h}]}\end{array}$ & $\begin{array}{c}1.3 \times 10^{10} \\
{[48 \mathrm{~h}]}\end{array}$ & $\begin{array}{c}0.99 \times 10^{10} \\
{[48 \mathrm{~h}]}\end{array}$ \\
\hline$Y_{P / S}[g / g]^{*}$ & $\begin{array}{l}0.96 \\
(96 \%)^{\mathrm{a}}\end{array}$ & $\begin{array}{c}1.06 \\
(106 \%)^{\mathrm{a}}\end{array}$ & $\begin{array}{c}1.02 \\
(102)^{a}\end{array}$ & $\begin{array}{l}1.05 \\
(53 \%)^{\mathrm{a}}\end{array}$ & $\begin{array}{l}0.845 \\
(70 \%)^{a}\end{array}$ & $\begin{array}{l}0.947 \\
(95 \%)^{\mathrm{a}}\end{array}$ \\
\hline$Q_{P}[g /(l \cdot h)]^{*}$ & 1.38 & 1.18 & 1.18 & 1.24 & 1.55 & 2.08 \\
\hline
\end{tabular}

*Glucose conversion, $\mathrm{YP}_{\mathrm{P} / \mathrm{S}}$ and $\mathrm{Q}_{\mathrm{P}}$ were calculated for values obtained in the $24 \mathrm{hrs}$ of the process. ${ }^{\mathrm{a}} \%$ of the theoretical yield. 
These findings and reports have prompted us to further investigate the utilization of the carbon sources in the molasses-wheat-stillage medium by the same L. plantarum strain.

In summary, distillery wastewater and molasses may be used as nitrogen and carbon sources for large-scale fermentation of $\mathrm{LAB}$, and thus help to avoid problems inherent in the use of animal-based nitrogen sources. The development of further media for LAB growth may eventually lead to a more efficient utilization of the waste streams from both distilleries and sugar mills.

\section{CONCLUDING REMARKS}

The results of this study suggest that wheat stillage, sugar beet molasses and yeast extract can be used as nitrogen and carbon sources for the production of $L$. plantarum on an industrial scale. The highest number of LAB $\left(1.6 \times 10^{10} \mathrm{cfu} / \mathrm{ml}\right)$ was achieved by the addition of $1.77 \mathrm{~g} / \mathrm{YE}$ to the $10 \%$ molasses-enriched sieved stillage, with $\mathrm{NH}_{4} \mathrm{OH}$ used for $\mathrm{pH}$ adjustment. Wheat stillage contains a substantial fraction of bran (solids), which must be removed at a defined stage of the process if the $\mathrm{LAB}$ will be used as starter cultures for the food industry. In other applications, such as ensilage inoculation or animal probiotic, the solids might be left in the medium.

The use of a fermentation medium consisting of distillery wastewater and molasses to obtain valueadded products (such as LAB biomass and lactic acid) is a possible step for classical ethanol production to move towards a biorefinery model production in which all by and waste products are utilized to increase produced values and reduce waste production. This enables a cost-effective utilization of the problematic wastewater from ethanol and sugar production.

Financial support: This work was financed by the Foundation for Strategic Research (MISTRA) programme for Domestication of micro-organisms (DOM). We thank Su-Lin Leong for critical reading of the manuscript.

\section{REFERENCES}

AGUIRRE-EZKAURIATZA, E.J.; AGUILAR-YÁÑEZ, J.M.; RAMÍREZ-MEDRANO, A. and ALVAREZ, M.M. (2010). Production of probiotic biomass (Lactobacillus casel) in goat milk whey: Comparison of batch, continuous and fed-batch cultures. Bioresource Technology, vol. 101, no. 8, p. 2837-2844. [CrossRef]

BRIENS, C.; PISKORZ, J. and BERRUTI, F. (2008). Biomass valorization for fuel and chemicals production - a review. International Journal of Chemical Reactor Engineering, vol. 6, no. 1. [CrossRef]

CHAUHAN, K.; TRIVEDI, U. and PATEL, K. (2007). Statistical screening of medium components by PlackettBurman design for lactic acid production by Lactobacillus sp. KCP01 using date juice. Bioresource Technology, vol. 98, no. 1, p. 98-103. [CrossRef]

DEMIRCI, A.; POMETTO, A.L.; LEE, B. and HINZ, P.N. (1998). Media evaluation of lactic acid repeated-batch fermentation with Lactobacillus plantarum and Lactobacillus casei Subsp. rhamnosus. Journal of Agricultural and Food Chemistry, vol. 46, no. 11, p. 4771-4774. [CrossRef]

DUMBREPATIL, A.; ADSUL, M.; CHAUDHARI, S.; KHIRE, J. and GOKHALE, D. (2008). Utilization of molasses sugar for lactic acid production by Lactobacillus delbrueckii subsp. delbrueckii mutant Uc-3 in batch fermentation. Applied and Environmental Microbiology, vol. 74, no. 1, p. 333-335. [CrossRef]

FU, W. and MATHEWS, A.P. (1999). Lactic acid production from lactose by Lactobacillus plantarum: Kinetic model and effects of $\mathrm{pH}$, substrate, and oxygen. Biochemical Engineering Journal, vol. 3, no. 3, p. 163-170. [CrossRef]

GAGGIIA, F.; MATTARELLI, P. and BIAVATI, B. (2010). Probiotics and prebiotics in animal feeding for safe food production. International Journal of Food Microbiology, vol. 141, supp. 1, p. S15-S28. [CrossRef]

GHAZI, I.; FERNANDEZ-ARROJO, L.; GOMEZ DE SEGURA, A.; ALCALDE, M.; PLOU, F.J. and BALLESTEROS, A. (2006). Beet sugar syrup and molasses as low-cost feedstock for the enzymatic production of fructooligosaccharides. Journal of Agricultural and Food Chemistry, vol. 54, no. 8, p. 2964-2968. [CrossRef]

GILLILAND, S.E. (1976). Preparation and storage of concentrated cultures of lactic streptococci. Journal of Dairy Science, vol. 60, no. 5, p. 805-809. [CrossRef]

GÖKSUNGUR, Y. and GÜVENÇ, U. (1999). Production of lactic acid from beet molasses by calcium alginate immobilized Lactobacillus delbrueckii IFO 3202. Journal of Chemical Technology and Biotechnology, vol. 74, no. 2, p. 131-136. [CrossRef]

HOFVENDAHL, K. and HAHN-HÄGERDAL, B. (1997). L-lactic acid production from whole wheat flour hydrolysate using strains of Lactobacilli and Lactococci. Enzyme and Microbial Technology, vol. 20, no. 4, p. 301-307. [CrossRef]

HORN, S.J.; ASPMO, S.I. and EIJSINK, V.G.H. (2005). Growth of Lactobacillus plantarum in media containing hydrolysates of fish viscera. Journal of Applied Microbiology, vol. 99, no. 5, p. 1082-1089. [CrossRef] 
LI, Z.; HAN, L.; JI, Y.; WANG, X. and TAN, T. (2010). Fermentative production of L-lactic acid from hydrolysate of wheat bran by Lactobacillus rhamnosus. Biochemical Engineering Journal, vol. 49, no. 1, p. 138-142. [CrossRef]

MONDRAGÓN-PARADA, M.E.; NÁJERA-MARTÍNEZ, M.; JUÁREZ-RAMÍREZ, C.; GALÍNDEZ-MAYER, J.; RUIZORDAZ, N. and CRISTIANI-URBINA, E. (2006). Lactic acid bacteria production from whey. Applied Biochemistry and Biotechnology, vol. 134, no. 3, p. 223-232. [CrossRef]

MUSSATTO, S.I.; FERNANDES, M.; MANCILHA, I.M. and ROBERTO, I.C. (2008). Effects of medium supplementation and $\mathrm{pH}$ control on lactic acid production from brewer's spent grain. Biochemical Engineering Journal, vol. 40, no. 3, p. 437-444. [CrossRef]

NARAYANAN, N.; ROYCHOUDHURY, P.K. and SRIVASTAVA, A. (2004). L(+) lactic acid fermentation and its product polymerization. Electronic Journal of Biotechnology, vol. 7, no. 2. [CrossRef]

NAVEENA, B.J.; ALTAF, M.; BHADRIAH, K. and REDDY, G. (2005). Selection of medium components by PlackettBurman design for production of $\mathrm{L}(+)$ lactic acid by Lactobacillus amylophilus GV6 in SSF using wheat bran. Bioresource Technology, vol. 96, no. 4, p. 485-490. [CrossRef]

OHMOMO, S.; DAENGSUBHA, W.; YOSHKAWA, H.; YUI, M.; NOZAKI, K.; NAKAJIMA, T. and NAKAMURA, I. (1988). Screening of anaerobic bacteria with the ability to decolorize molasses melanoidin. Agricultural and Biological Chemistry, vol. 52, no. 10, p. 2429-2435.

OMER, Z.S.; JACOBSSON, K.; EBERHARD, T.H. and JOHANSSON, L.K.-H. (2010). Bacteria considered as biocontrol agents to control growth of white clover in golf courses. Acta Agriculturae Scandinavica, Section $B$ Plant Soil Science, vol. 60, no. 3, p. 193-198. [CrossRef]

PASSOS, F.V.; FLEMING, H.P.; OLLIS, D.F.; FELDER, R.M. and MCFEETERS, R.F. (1994). Kinetics and modeling of lactic acid production by Lactobacillus plantarum. Applied Environmental Microbiology, vol. 60, no. 7, p. 2627-2636.

PEEBLES, M.M.; GILLILAND, S.E. and SPECK, M.L. (1969). Preparation of concentrated lactic streptococcus starters. Applied Microbiology, vol. 17, no. 6, p. 805-810.

SCHIRALDI, C.; ADDUCI, V.; VALLI, V.; MARESCA, C.; GIULIANO, M.; LAMBERTI, M.; CARTENI, M. and DE ROSA, M. (2003). High cell density cultivation of probiotics and lactic acid production. Biotechnology and Bioengineering, vol. 82, no. 2, p. 213-222. [CrossRef]

TONDEE, T. and SIRIANUNTAPIBOON, S. (2008). Decolorization of molasses wastewater by Lactobacillus plantarum No. PV71-1861. Bioresource Technology, vol. 99, no. 14, p. 6258-6265. [CrossRef]

WOHLGEMUTH, S.; LOH, G. and BLAUT, M. (2010). Recent developments and perspectives in the investigation of probiotic effects. International Journal of Medical Microbiology, vol. 300, no. 1, p. 3-10. [CrossRef]

YE, Z.-L.; ZHENG, Y.; LI, Y.-H. and CAI, W.-M. (2008). Use of starter culture of Lactobacillus plantarum BP04 in the preservation of dining-hall food waste. World Journal of Microbiology and Biotechnology, vol. 24, no. 10, p. 2249-2256. [CrossRef]

\section{How to cite this article:}

KRZYWONOS, M. and EBERHARD, T. (2011). High density process to cultivate Lactobacillus plantarum biomass using wheat stillage and sugar beet molasses. Electronic Journal of Biotechnology, vol. 14, no. 2 http://dx.doi.org/10.2225/vol14-issue2-fulltext-10 